\title{
Young Children's Temperament and Mother's Parenting Profile Analysis: The Relevance of Executive Function
}

\author{
Hye Rin Lee ${ }^{1}$, Sunhee Kim² \\ M. A., Department of Child Development and Family Studies, Pusan National University, Busan, Korea ${ }^{1}$ \\ Professor, Department of Child Development and Family Studies, Pusan National University, Busan, Korea ${ }^{2}$ \\ 유아의 기질과 어머니 양육행동 프로파일 분석: 실행기능과의 관련성 \\ 이혜린 ${ }^{1}$, 김선희 ${ }^{2}$ \\ 부산대학교 아동가족학과 석사 ${ }^{1}$, 부산대학교 아동가족학과 교수 ${ }^{2}$
}

\begin{abstract}
Objectives: The purpose of this study was to identify young children's temperaments and their mothers' corresponding parenting behavior profiles by applying latent profile analysis, and to explore how they relate to young children's executive functions in each latent profile.

Methods: Participants included 294 children (146 boys and 148 girls) aged 3-5 years and their mothers. A scale of child temperament: EAS (20 questions), a scale of mother's parenting (34 questions), and a scale of executive functions: brief-p (43 questions) were used.

Results: Young children's temperaments and their mothers' parenting behavior profiles were classified into three groups. They were: 'negative emotionality child + inconsistent parenting (40\%)', 'shy child + authoritative parenting (14\%)', and 'sociable child + authoritative parenting (46\%)'. As per the results of the three-step approach, there were significant differences in the executive functions (inhibition, shifting, and working memory) according to the three profiles.

Conclusion: This study is meaningful because it identified various aspects of a young child's temperament with respect to his/her mother's parenting. Identifying differences in the executive functions of young children will also help provide implications for the necessary preventative involvement of young child with various temperament characteristics and mothers.
\end{abstract}

Keywords: child's temperament, mother's parenting, child's executive function, latent profile analysis

\section{Introduction}

최근 뇌 과학의 발전에 따라 전두엽의 여러 영역이 인간의 행동과 정서에 핵심 역할을 하는 것으로 밝혀지면서(Zhou, Chen, \& Main, 2012), 다수의 연구자들이 전두엽 발달과 밀접 한 관련성이 있는 실행기능에 주목하고 있다.

실행기능이란 미래의 목표를 달성하기 위해 적절한 문제 해결 전략을 세우고 유지하며(Welsh, Pennington, \& Grosser,

Corresponding Author: Sunhee Kim, Professor, Department of Child Development and Family Studies, Pusan National University, 2, Busandaehak-ro 63beon-gil, Geumjeong-gu, Busan, Korea

E-mail: kremedy@pusan.ac.kr
1991), 목표 지향적 활동에 있어 자신의 신체, 인지, 행동을 의 식적으로 조절, 통제할 수 있는 고차원적인 인지능력으로 억 제(inhibition), 전환(shifting), 작업기억(working memory)으 로 구분된다(Miyake, Friedman, Emerson, Witzki, Howerter, \& Wager, 2000). 억제는 지배적이거나 우세한 반응을 계획적이 고 신중하게 무시할 수 있는 능력, 전환은 여러 가지 조작과 마 음상태를 유연하게 바꿀 수 있는 능력, 작업기억은 목표를 달 성하기 위해 필요한 정보들을 저장하며, 기존의 정보를 수정

(C)The Korean Association of Child Studies

This is an Open Access article distributed under the terms of the Creative Commons Attribution Non-Commercial License (http:// creativecommons.org/licenses/by-nc/4.0) which permits unrestricted noncommercial use, distribution, and reproduction in any medium, provided the original work is properly cited. 
할 수 있는 능력을 의미한다.

실행기능은 영아기부터 출현하기 시작하여 청소년기까지 지속적으로 발달하며, 특히 유아기에 급속하게 발달하는 것으 로 알려져 있다(Carlson, 2005; Garon, Bryson, \& Smith, 2008). 또한 유아기의 실행기능은 학교준비도(M. Cha, 2018), 언어능 력(Y.-M. Kim, 2018), 사회적 유능성(B. Y. Kim, 2016) 등과 관 계되는 요인으로 유아기 이후의 성공적인 적응과 발달에 중요 한 요소이다.

유아기의 실행기능 발달에 영향을 미치는 요인들을 살펴보 면, 기질(M. Cha \& Kim, 2018), 지능(H. J. Kim \& Hong, 2011), 정서지능(Seo \& Park, 2011) 등 유아의 개인 내적 요인과 어머 니의 양육행동(M. Cha \& Kim, 2018), 어머니의 언어통제유형 (M.-H. Kim, 2014), 모의 상호작용 양상(K. Cha, 2015) 등 외적 요인으로 설명되고 있다.

기질은 생의 초기에 드러나는 유전적 성격특성으로(Buss \& Plomin, 2014), 생물학적 - 행동적 측면에서 실행기능과 밀접 한 관련성이 있다. 신경심리학에 따르면 기질의 일부 하위 영 역은 실행기능과 마찬가지로 전두엽 회로의 영향을 받고 있으 며, 까다로운 기질 특성과 실행기능의 결함은 유사한 행동 프 로파일을 나타낸다(Giancola, 1995; McManis, Kagan, Snidman, \& Woodward, 2002). 관련 선행연구에서도 활동수준이 낮고, 긍정적인 기분을 표현하고, 행동이 규칙적이며, 새로운 자극 에 쉽게 접근하고, 변화에 빠르게 적응하는 기질의 유아는 실 행기능이 높은 것으로 나타났다. 반면, 신체적 움직임이 활발 하고, 생리적 주기가 불규칙하며, 새로운 자극에 대해 부정적 으로 반응하고, 적응성이 낮은 기질의 유아는 실행기능이 낮 은 것으로 보고되고 있어(M. Cha \& Kim, 2018; Kong \& Lim, 2012), 유아의 기질과 실행기능과의 관련성을 확인할 수 있다.

한편 영유아기는 뇌의 성장 급등기로, 생의 초기 환경으 로부터 자극받은 뉴런이 시냅스를 지속적으로 생산하게 되 고, 자극을 받지 못한 시냅스는 제거되는 시냅스 가지치기 (synaptic pruning) 과정을 거친다. 따라서 발달 과정에 놓인 영 유아들이 받는 환경적 자극에 따라 뇌의 기능의 차이를 가져 오기 때문에 초기 관계적 경험이 유아의 신경인지 발달에 중 요한 역할을 한다(Nelson \& Bloom, 1997).

그 중 가정은 유아가 맞이하는 최초의 환경이며, 특히 어머 니는 유아와 가장 많은 시간을 보내는 대상이다. 따라서 어머 니의 실제적인 양육행동은 유아의 실행기능 발달에 많은 영향 을 미친다. 관련 선행연구에서 온정적이고 민감하며 자율성을 지지하는 등과 같은 긍정적 양육은 유아의 실행기능 발달을 촉진하는 반면, 어머니의 과보호적이고, 통제하는 양육은 실
행기능 발달을 저해하는 것으로 일관되게 보고되고 있다(M. Cha \& Kim, 2018; Kong \& Lim, 2012; J.-I. Lee \& Yu, 2019; Y.-J. Lee, Kong, \& Lim, 2014; Yoo \& Kim, 2017). 즉, 어머니의 양육 행동은 유아의 기질과 함께 유아의 실행기능의 개인차를 예측 하는 중요한 요인이다.

그러나 지금까지의 대다수 선행연구들은 실행기능과 관련 하여 유아의 기질과 어머니 양육행동 각각의 영향력을 검증함 으로써, 유아의 특성과 어머니의 양육행동 간의 역동적인 관 련성은 간과한 채 연구가 이루어졌다. Thomas와 Chess (1977) 는 선천적으로 타고난 기질이 환경과 상호작용함으로써 표현 되어 이후 발달에 영향을 미치게 된다고 하였다. 즉, 기질 자체 보다 유아의 기질과 환경사이의 상호작용이 유아의 발달적 결 과에 더욱 중요함을 제안하였다. 이러한 측면에서 볼 때, 유아 의 발달에 가장 큰 기여를 하는 어머니의 특성은 유아의 기질 과 상호작용함으로써, 유아의 실행기능 발달에 중요한 영향 을 미칠 수 있다(Rochette \& Bernier, 2016; Suor, Sturge-Apple, Davies, \& Jones-Gordils, 2019). 이에 본 연구에서는 유아의 기 질과 어머니 양육행동을 동시에 고려하여 실행기능 발달을 살 펴보고자 한다.

하지만 실행기능과 관련하여 기존의 상호작용 효과를 살 펴본 연구는 변수중심(variable-centered)접근에서 특정 결과에 대한 선택된 변수의 영향력만을 제공하기 때문에(Laursen \& Hoff, 2006), 유아와 어머니의 상호작용 패턴에 있어 잠재된 속성을 파악하기에는 한계가 있다. 기질과 양육행동에 대한 연구(Cheon, 2002; B.-K. Park, 2013)를 살펴보면, 유아가 동일 한 기질적 특성을 가지고 있더라도 어머니의 양육행동이 동일 하지 않음을 보고하고 있다. 일반적으로 유아가 긍정적인 기 분을 표현할수록 어머니가 애정적·자율적인 긍정적 양육을 보이는 반면, 유아가 자주 화를 내는 기질을 지닐수록 유아의 이런 행동이 어머니를 지치고 힘들게 만들어, 어머니가 유아 를 수용하기보다는 거부적이고 통제적인 부정적 양육을 보이 는 것으로 나타났다. 반면 일부 연구에서는 어머니는 순한 기 질의 유아를 더 수월하게 통제하기 위해 지배적인 양육행동을 보이기도 하며(Cheon, 2002), 활동수준이 높고, 짜증과 화를 잘 내는 유아에 대해 어떤 부모는 이러한 특성을 아이다운 모 습으로 지각하여 유아에게 애정과 관심을 가지고 더 열중하기 도 한다(Caron \& Miller, 1981). 이처럼 상반된 결과들은 유아 의 기질과 어머니 양육 간 관계에서 개인차가 존재하며, 집단 내에서 이질성이 내재됨을 암시한다. 하지만 기존의 변수 중 심 접근 방식에서 유아와 어머니의 상호작용 패턴을 분석하고 해석하기에는 어려움이 있다(Dalimonte-Merckling \& Brobhy- 
Table 1

General Characteristics of Participants

\begin{tabular}{clc}
\hline \multicolumn{1}{c}{ Characteristics } & Categories & Frequency (\%) \\
\hline Gender & Boy & $146(49.7)$ \\
& Girl & $148(50.3)$ \\
Age & 3 & $91(31.0)$ \\
& 4 & $91(31.0)$ \\
& 5 & $112(38.0)$ \\
\hline
\end{tabular}

Note. $N=294$.

Herb, 2019).

이에 본 연구에서는 잠재프로파일 분석(Latent Profile Analysis [LPA])을 적용하여 유아의 실행기능과 관련되는 유아 의 기질과 어머니의 양육행동 프로파일을 탐색하고자 한다. 잠재프로파일 분석은 집단 내 이질성을 허용하여 개인의 특성 에 관심을 갖는 개인-중심 접근방법( person-centered approach) 으로써, 질적으로 다른 여러 개의 잠재집단을 발견해내는데 유용하다. 따라서 본 연구의 목적은 유아의 기질과 어머니의 양육행동을 동시에 고려하여 프로파일을 탐색함으로써 각 프 로파일 간의 이질적인 특성을 규명하고, 유아의 기질과 어머 니 양육행동 프로파일에 따른 유아의 실행기능 차이를 살펴 보는 것이다. 이러한 방법은 단순히 유아의 기질과 어머니 양 육행동이 유아의 실행기능에 영향을 미친다는 결과를 넘어서, 집단 내 유아와 어머니의 특성과 관계를 공유하는 다양한 프 로파일을 추정할 수 있다. 또한 발달적 특성이 다른 실행기능 의 하위요인인 억제, 전환, 작업기억(M.-J. Lee \& Hong, 2006; Maeng, Jeong, \& Kwon, 2014)이 유아의 기질 그리고 어머니 양 육행동과 어떠한 관련성이 있는지 검증함으로써, 다양한 기질 적 특성을 가진 유아와 그들의 어머니에게 필요한 시사점을 제공하여 유아의 실행기능 발달을 돕고자 한다.

\section{연구문제 1}

유아의 기질과 어머니의 양육행동에 따른 프로파일은 몇 개로 나누어지며, 각 프로파일의 특징은 어떠한가?

\section{연구문제 2}

유아의 기질과 어머니의 양육행동 프로파일에 따른 유아의 실행기능의 하위 요인인 억제, 전환, 작업기억의 차이는 어떠 한가?

\section{Methods}

\section{연구대상}

본 연구의 대상은 $\mathrm{B}$ 시에 소재한 9 개 어린이집과 1 개 유치원에 재원하고 있는 만 $3,4,5$ 세 유아 294 명과 그들의 어머니이다. 본 연구대상의 특징은 Table 1 에 제시된 바와 같다. 유아의 연 령과 성별은 각각 3세 91명(31.0\%), 4세 91명(31.0\%), 5세 112 명(38.0\%)이며, 남아 146 명(49.7\%), 여아 148 명(50.3\%)이다.

\section{연구도구}

\section{유아의 실행기능}

유아의 실행기능을 측정하기 위해서 Gioia, Isquith, Guy와 Kenworthy (2000)가 개발한 유아용 실행기능척도(Behavior Rating Inventory of Executive Function-Preschool Version [BRIEF-P])를 Seo와 Park (2011)이 번안한 척도의 인지적 실행기능 영역을 사용하였다. 이 척도는 억제(16문항), 전환(10문항), 작업기억 (17문항) 총 3개의 하위영역(43문항)으로 구성되어있다. 억제 는 우세한 반응을 신중하고 계획적으로 무시할 수 있는 능력 을 의미하며, 전환은 여러 가지 조작과 마음상태를 유연하게 바꿀 수 있는 능력을 의미한다. 작업기억은 새로운 정보들을 단순히 기억하고 저장하는 것뿐만 아니라 기존의 정보들과 비 교하여 새로운 정보로 교체하거나 기존의 정보를 수정할 수 있는 능력을 의미한다. 이 척도는 4점 Likert식 척도이며 유아 의 어머니가 평가한다. 점수가 높을수록 유아의 실행기능이 낮은 것을 의미하지만, 본 연구에서는 점수가 높을수록 각 요 인의 특성이 높음을 의미하도록 모든 문항을 역채점하였다. 하위요인별 신뢰계수(Cronbach's $\alpha$ )는 억제가 .91, 전환이 .83, 작업기억이 .93으로 나타났다.

$$
\text { 유아의 기질 }
$$

유아의 기질을 측정하기 위해서 Buss와 Plomin (1986)의 Emotionality, Activity, Sociability (EAS)를 한국아동패널 연구진이 번 안한 것을 사용하였다. 이 척도는 활동성(5문항), 정서성(5문 항), 사회성(10문항) 총 3 개의 하위영역(20문항)으로 구성되어 있다. 활동성은 활동수준에 대한 내용으로 새로운 것에 대해 호기심을 보이고 전반적으로 움직임이 많은 것을 의미하며, 정서성은 기분이 쉽게 나빠지고 화를 잘 내며 정서적 반응을 
보이는 성향, 사회성은 혼자 있는 것보다 여러 사람과 함께 어 울리는 것을 좋아하는 친사회적인 성향을 의미한다. 이 척도 는 5점 Likert식 척도이며, 유아의 어머니가 평가한다. 각 영역 의 점수가 높을수록, 영역별 특성이 높은 것을 의미한다. 하위 요인별 신뢰계수(Cronbach's $\alpha$ )는 활동성은 .63, 정서성은 .78, 사회성은 .75로 나타났다.

\section{어머니 양육행동}

어머니 양육행동을 측정하기 위해 J. Park (2001)이 제작한 양 육행동 척도를 사용하였다. 이 척도는 온정·격려(11문항), 한 계설정(8문항), 과보호·허용(7문항), 거부·방임(8문항) 총 4 개 의 하위영역(34문항)으로 구성되어있다. 온정·격려는 어머니 가 자녀에게 온정적인 태도로 긍정적이고 수용적인 양육행동 을 보이는 것을 의미하며, 한계설정은 어머니의 규준에 따라 자녀의 행동에 통제를 가하는 양육행동을 말한다. 또한, 과보 호·허용은 어머니가 자녀의 요구에 무조건 따르며 적절한 통 제를 하지 않는 양육행동을 의미하며, 마지막으로 거부.방임 은 어머니가 자녀와의 상호작용을 기피하는 양육행동을 의미 한다. 이 척도는 5점 Likert식 척도이며, 유아의 어머니가 평가 한다. 각 영역의 점수가 높을수록, 영역별 특성이 높은 것을 의 미한다. 하위요인별 신뢰계수(Cronbach's $\alpha$ )는 온정·격려 .86, 한계설정 .75 , 과보호 .63 , 거부. 방임은 .80으로 나타났다.

\section{연구절차}

유아의 실행기능, 기질, 어머니 양육행동 및 조사대상자의 일 반적 특성(성별, 나이)에 관한 내용으로 질문지를 구성하여 2019년 7월 20일부터 2019년 8월 31일까지 설문조사를 통해 자료를 수집하였다. 각 학급의 교사에게 설문내용을 설명하고 설문조사에 대한 협조를 구한 뒤, 유아를 통해 설문지를 가정 에 전달하고 회수하였다. 배포된 430부 중에서 총 306부가 회 수되었으며, 이 중 누락되거나 불성실한 응답자료 12 부를 제 외한 294부가 최종 분석 자료로 사용되었다.

\section{자료분석}

본 연구의 자료분석은 SPSS 20.0 (IBM Co., Armonk, NY)과 Mplus 8 (Muthén \& Muthén, Los Angeles, CA)을 사용하여 다음 과 같은 방법으로 분석하였다. 첫째, 만 3-5세 유아의 인구학 적 배경 특성을 알아보기 위해 빈도와 백분율을 산출하고, 각
측정도구의 신뢰도 검증을 위해 Cronbach's $\alpha$ 계수를 산출하 였다. 둘째, 유아의 실행기능, 기질, 어머니 양육행동 간의 관 계를 알아보기 위해 Pearson 적률상관분석을 실시하였다. 셋 째, 유아의 기질과 어머니 양육행동 잠재프로파일을 확인하기 위하여 잠재프로파일 분석을 실시하였다. 넷째, 유아의 기질 과 어머니 양육행동 프로파일에 따른 실행기능의 하위요인인 억제, 전환, 작업기억의 차이를 확인하기 위해 3 단계 접근방법 (three-step approach) 중 DU3STEP을 실시하였다. 3단계 접근 방법은 잠재프로파일 모형에 독립변수와 종속변수가 추가될 때 잠재프로파일 수와 해석이 변할 수 있는 가능성을 통제하 기 위해 개발된 방법으로, 분류 시 독립변수와 종속변수의 영 향력을 통제할 수 있을 뿐만 아니라 분류 오류를 고려할 수 있 다(S. Hong, 2019). 이 방법은 독립, 종속변수가 없는 기본 혼 합모형을 추정하는 1 단계, 각 개인에 대해 가장 가능성이 높은 잠재프로파일을 추정하는 2 단계, 분류오류를 고려한 상태에 서 독립, 종속 변수의 효과를 추정하는 3 단계로 이루어진다.

\section{Results}

\section{주요 변인들 간의 관계}

유아의 실행기능과 유아의 기질, 어머니 양육행동의 상관관계 를 살펴보기 위해 각 변인들의 기술통계치와 Pearson 적률상관 계수를 산출하여 Table 2에 제시하였다.

유아 실행기능의 평균은 억제 3.62 , 전환 3.62 , 작업기억 3.61 순으로 높게 나타났으며, 유아 기질의 평균은 활동성 3.84 , 사회성 3.42 , 정서성 2.56 순으로 높게 나타났다. 어머 니의 양육행동의 평균은 온정·격려 4.03 , 한계설정 3.61 , 거 부·방임 2.54, 과보호·허용 2.22 순으로 높게 나타났다.

유아의 실행기능의 하위유형(억제, 전환, 작업기억)과 기 질 간의 상관관계를 살펴보면, 유아의 억제는 사회성 $(r=.17, p$ $<.01)$ 과는 정적 상관, 정서성 $(r=-.51, p<.01)$ 과 부적 상관을 보였으며, 활동성과는 유의미한 상관이 없는 것으로 나타났 다. 이는 유아가 사회성이 높고, 정서성이 낮을수록 억제 능력 이 높은 것으로 해석할 수 있다. 또한 유아의 전환은 활동성 $(r$ $=.33, p<.01)$, 사회성 $(r=.45, p<.01)$ 과는 정적상관, 정서성 $(r$ $=-.46, p<.01)$ 과는 부적상관이 나타났다. 이는 유아가 활동성 과 사회성이 높고, 정서성이 낮을수록 전환능력이 높은 것으 로 해석할 수 있다. 유아의 작업기억은 활동성 $(r=.17, p<.01)$ 과 사회성 $(r=.25, p<.01)$ 과는 정적상관, 정서성 $(r=-.44, p<$ 
Table 2

Means, Standard Deviations, and Correlations Among Variables

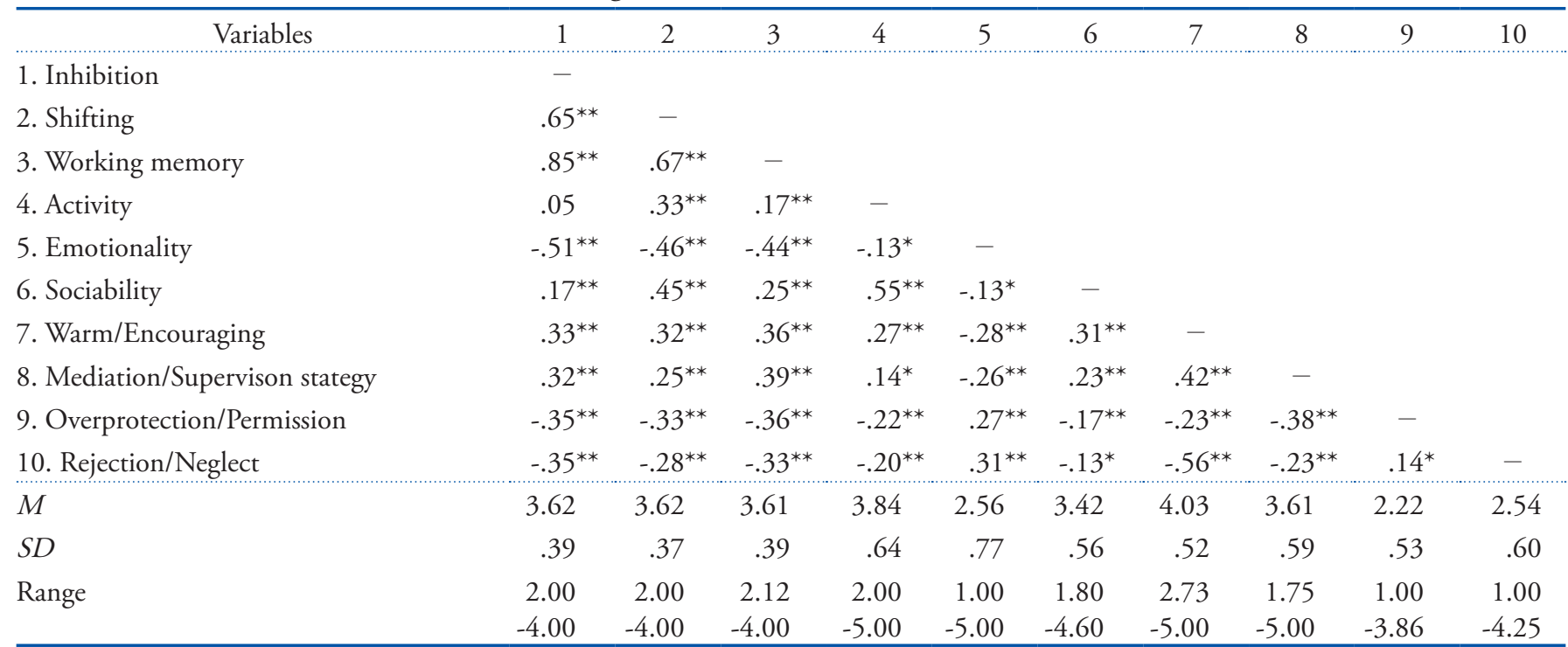

Note. $N=294$.

${ }^{*} p<.05 .{ }^{* *} p<.01$.

.01)과는 부적상관이 나타났다. 이는 유아가 활동성, 사회성이 높고 정서성이 낮을수록 작업기억 능력이 높은 것으로 해석할 수 있다.

유아의 실행기능의 하위유형(억제, 전환, 작업기억)과 어머 니 양육행동 간의 상관관계를 살펴보면, 실행기능의 모든 하 위유형과 어머니의 온정·격려 및 한계설정과는 정적 상관이, 과보호·허용 및 거부·방임과는 부적 상관이 나타났다 $(r=-.36$ .39, $p$ <.01). 이는 어머니의 온정·격려, 한계설정 양육행동 이 높을수록, 과보호·허용, 거부.방임 양육행동이 낮을수록 유아의 실행기능이 높은 것으로 해석할 수 있다.

유아의 기질과 어머니 양육행동 간의 상관관계를 살펴보 면, 유아의 활동성은 어머니의 온정·격려 $(r=.27, p<.01)$ 및 한계설정 $(r=.14, p<.05)$ 과 정적 상관이, 과보호·허용 $(r=-.22$, $p<.01)$ 및 거부. 방임 $(r=-.20, p<.01)$ 과는 부적 상관이 나타 났다. 이는 유아가 활동적일수록 어머니가 온정·격려, 한계설 정 양육행동을 많이 보이고, 거부·방임, 과보호·허용 양육행 동을 적게 보이는 것으로 볼 수 있다. 유아의 정서성은 어머니 의 온정·격려 $(r=-.28, p<.01)$ 및 한계설정 $(r=-.26, p<.01)$ 과 부적 상관이, 과보호·허용 $(r=.27, p<.01)$ 및 거부·방임 $(r$ $=.31, p<.01)$ 과는 정적 상관이 나타났다. 이는 유아가 정서 성이 높을수록 어머니가 온정·격려, 한계설정 양육행동을 적 게 보이고, 거부·방임, 과보호·허용 양육행동을 많이 보이는 것으로 볼 수 있다. 유아의 사회성은 어머니의 온정·격려 $(r=$
$.31, p<.01)$ 및 한계설정 $(r=.23, p<.01)$ 과 정적 상관이, 과보 호·허용 $(r=-.17, p<.01)$, 거부·방임 $(r=-.13, p<.05)$ 과는 부 적 상관이 나타났다. 이는 유아가 사회성이 높을수록 어머니 가 온정·격려, 한계설정 양육행동을 많이 보이고, 과보호·허 용, 거부 ·방임 양육행동을 적게 보이는 것으로 볼 수 있다.

\section{유아의 기질과 어머니 양육행동의 잠재프로파일}

\section{잠재프로파일 수 결정}

유아의 기질과 어머니 양육행동의 잠재프로파일 수를 결정하 기 위해 모형비교 검증을 실시한 결과는 다음의 Table 3과 같다.

$\mathrm{AIC}, \mathrm{BIC}$ 와 $\mathrm{aBIC}$ 값이 작을수록, Entropy가 1 에 가까울수 록 적절한 모형이라 볼 수 있다. 잠재프로파일 수가 많아질수 록 $\mathrm{AIC}, \mathrm{BIC}$ 와 $\mathrm{aBIC}$ 값이 줄어들지만, 잠재프로파일 수가 3 개 일 때 Entropy가 1 에 더 가까우며, LMRLRT $p$ 값은 .04, BLMR $p$ 값은 .00 이므로 가장 좋은 모형이라 볼 수 있다. 더불어 통 계적-이론적 해석가능성과 간명성을 고려하여 잠재프로파일 수가 3 개인 모형을 최종모형으로 결정하였다.

\section{유아의 기질과 어머니 양육행동 잠재프로파일 특징}

유아의 기질과 어머니 양육행동에 대한 3 개의 잠재프로파일 
Table 3

Information Criteria and Model Fit Indices for 2 to 5 Latent Profiles

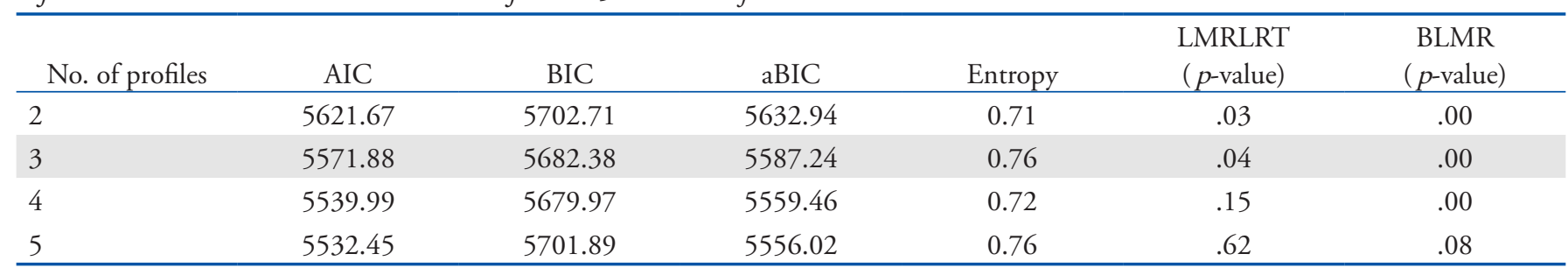

Note. $N=294$.

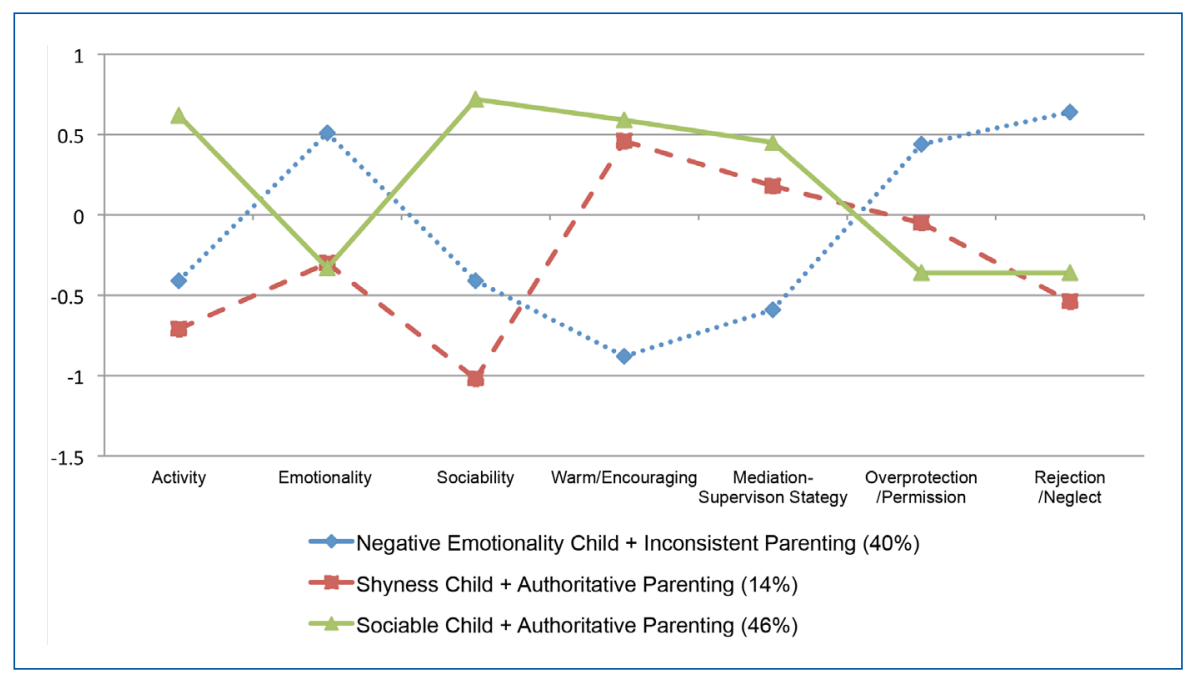

Figure 1. Characteristics of latent profiles on the indicators of child's temperament and mother's parenting.

Table 4

Characteristics of Latent Profiles on the Indicators of Child's Temperament and Mother's Parenting

\begin{tabular}{|c|c|c|c|c|c|c|c|}
\hline Latent profiles & Activity & Emotionality & Sociability & Warm/Encouraging & $\begin{array}{c}\text { Mediation/ } \\
\text { Supervison stategy }\end{array}$ & $\begin{array}{c}\text { Overprotection/ } \\
\text { Permission }\end{array}$ & $\begin{array}{c}\text { Rejection/ } \\
\text { Neglect }\end{array}$ \\
\hline Class 1. & -.41 & .51 & -.41 & -.88 & -.59 & .44 & .64 \\
\hline Class 2. & -.71 & -.30 & -1.02 & .46 & .18 & -.05 & -.54 \\
\hline Class 3. & .62 & -.33 & .72 & .59 & .45 & -.36 & -.36 \\
\hline
\end{tabular}

Note. $\mathrm{M}$ is based on $z$-score.

Class 1 = negative emotionality child + inconsistent parenting; Class $2=$ shyness child + authoritative parenting; Class $3=$ sociable child + authoritative parenting.

집단의 특징은 다음의 Figure 1과 같다. 각 잠재프로파일집단 의 특성을 파악하기 위해 표준화 점수( $z$ 점수)의 평균을 산출 하여 다음의 Table 4에 제시하였다.

첫 번째 잠재프로파일은 $40 \%$ 가 이 집단에 포함되어있는 것 으로 나타났다. 이 프로파일의 특성을 살펴보면, 유아의 기질은 부정적 정서성이 가장 높게 나타났다. 또한 어머니 양육행동은 온정·격려, 한계설정이 낮고, 과보호·허용, 거부·방임이 높게 나타났다. 이러한 양육행동은 Maccoby와 Martin (1983)의 양육 행동 중 허용적(permissive)양육과 방임적(neglectful) 양육이 함
께 나타난 유형과 유사하다. 즉, 어머니가 규칙에 따라서 자녀 를 통제하기보다는 어머니의 상황에 따라 과보호·허용적인 양 육과 거부·방임적인 양육이 함께 나타나는 비일관적인 양육으 로 볼 수 있다. 따라서 본 프로파일은 부정적인 정서를 잘 표현 하고, 달래기 어려운 유아에게 어머니가 온정적이고 규칙에 따 라 자녀를 통제하기보다는 과보호·허용, 거부·방임적인 집단 으로 '부정적 정서성 유아 + 비일관적 양육'으로 명명하였다.

두 번째 프로파일은 $14 \%$ 가 이 집단에 포함되어있는 것으 로 나타났다. 이 프로파일의 특성을 살펴보면, 유아의 기질은 
Table 5

Executive Function by Latent Profiles of Child's Temperament and Mother's Parenting

\begin{tabular}{|c|c|c|c|c|c|}
\hline & Class 1. & Class 2. & Class 3. & & \\
\hline & $M(S D)$ & $M(S D)$ & $M(S D)$ & $\chi^{2}$ & Scheffé \\
\hline Inhibition & $3.35(.05)$ & $3.84(.03)$ & $3.77(.03)$ & $87.43^{* * *}$ & $2=3>1$ \\
\hline Working memory & $3.33(.04)$ & $3.80(.12)$ & $3.81(.05)$ & $88.19^{* * *}$ & $2=3>1$ \\
\hline
\end{tabular}

Note. $N=294.1$ = class $1 ; 2$ = class $2 ; 3=$ class 3.

${ }^{* * *} p<.001$.

활동성과 사회성이 다른 프로파일 집단에 비해 낮게 나타났 다. 또한 어머니 양육행동은 온정·격려, 한계설정이 높고, 과 보호-허용, 거부· 방임이 낮게 나타났다. 이러한 양육행동은 Maccoby와 Martin (1983)의 양육행동 중 민주적(authoritative) 양육과 유사하다. 따라서 본 프로파일은 활동수준이 낮고, 다 른 사람과 어울려 놀기 보다는 혼자 노는 것을 좋아하는 성향 을 가진 유아에게 어머니가 온정적이고 자녀의 행동을 관심을 가지는 집단으로 ‘수줍음 유아 + 민주적 양육’으로 명명하였다.

세 번째 프로파일은 $46 \%$ 가 이 집단에 포함되어 있는 것을 나타났다. 이 프로파일의 특성을 살펴보면, 유아의 기질은 활 동성과 사회성이 다른 프로파일 집단에 비해 높게 나타났다. 또한 어머니 양육행동은 온정·격려, 한계설정이 높고, 과보 호·허용, 거부· 방임이 낮게 나타났다. 따라서 본 프로파일은 활동수준이 높고, 다른 사람과 어울려 놀기를 좋아하는 성향 을 가진 유아에게 어머니가 온정적인 태도로 규칙에 따라 자 녀를 통제하는 양육을 보이는 '사교성 유아 + 민주적 양육'으 로 명명하였다.

\section{유아의 기질과 어머니 양육행동 잠재프로파일에 따른 유아의 실행기능 차이}

유아의 기질과 어머니 양육행동 잠재프로파일 집단 따라 유아 의 실행기능에서 어떠한 차이가 있는지 알아보기 위해 3 단계 접근방법을 실시한 결과를 다음의 Table 5에 제시하였다.

3 단계 접근방법 결과 모든 잠재집단은 실행기능의 억제 (chi-square $=87.43, p<.001)$, 전환 (chi-square $=152.53, p<$ .001 )과 작업기억(chi-square $=88.19, p<.001$ )에서 집단 간 차 이가 유의하였다.

구체적으로 억제는 수줍음 유아 + 민주적 양육 집단과 사교 성 유아 + 민주적 양육 집단이 부정적 정서성 유아 + 비일관적 양육 집단보다 높은 것으로 나타났다. 전환은 사교성 유아 + 민주적 양육 집단이 부정적 정서성 유아 + 비일관적 양육과 수
줍음 유아 + 민주적 양육 집단보다 높은 것으로 나타났다. 작 업기억은 수줍음 유아 + 민주적 양육 집단과 사교성 유아 + 민 주적 양육 집단이 부정적 정서성 유아 + 비일관적 양육 집단보 다 높은 것으로 나타났다.

\section{Discussion}

본 연구의 목적은 유아의 기질과 어머니 양육행동에 따른 프 로파일을 분류함으로써 유아의 기질과 어머니 양육행동의 상 호작용 양상을 확인하고, 각 프로파일에 따른 실행기능의 차 이를 살펴보는 것이다. 주요 연구결과를 요약하고 논의하면 다음과 같다.

연구문제 1 과 관련하여, 유아의 기질과 어머니 양육행동의 프로파일을 확인한 결과, 부정적 정서성 유아 + 비일관적 양육 (40\%), 수줍음 유아 + 민주적 양육 $(14 \%)$, 사교성 유아 + 민주 적 양육(46\%)의 3 가지 프로파일로 분류되었다.

가장 많은 유아와 어머니가 속해 있는 사교성 유아 + 민주 적 양육 프로파일은 유아의 활동성과 사회성 기질, 그리고 어 머니의 온정·격려와 한계설정 양육행동이 높게 나타났다. 이 러한 결과는 유아의 높은 활동성, 사회성, 낮은 정서성 기질과 어머니의 온정적 양육행동(S. L. Kim, 2016), 애정적 양육행동 (M. J. Kim \& Lee, 2011)간의 정적 관련성을 확인한 연구와 일 치한다. 구체적으로 살펴보면 사교성 유아 + 민주적 양육 프로 파일의 유아는 활동성과 사회성이 동시에 높은 기질적 특성을 보인다. 일반적으로 활동성은 신체적 움직임이 활발하고 즉흥 적인 행동을 하는 특성으로 유아의 발달을 저해하는 기질 요 인으로 밝혀져 왔다. 반면, 사회성은 다른 사람과 어울리는 것 을 선호하는 성향으로 유아의 적응적인 발달과 관련된 기질 요인이다. 본 연구에서 유아의 기질을 다차원적인 관점에서 유형화한 결과, 활동성과 사회성이 동시에 높게 나타났다. 이 러한 결과는 활동성과 사회성이 유사한 특성을 공유하는 기질 
요인임을 추측할 수 있다. 선행연구에서 활동수준이 높은 유 아는 새로운 친구를 사귀기 위한 개입을 많이 하며(E. Y. Lee, 2009), 또래와 활발하게 상호작용을 하는 것으로 보고되었다 (H. J. Lim, 2014). 이는 유아의 활동성이 환경을 탐색하고 다 른 사람에게 접근하는 것을 용이하게 함으로써, 또래와 어울 리는 과정에서 원활하게 작용하는 것으로 볼 수 있다. 즉, 본 연구에서의 사교성 기질은 사회적인 상황에서 적극성을 가지 고 다른 사람과 어울리는 활기 있는 특성으로 설명할 수 있다. 이러한 결과는 유아의 활동성과 사회성이 높은 정적 관련성을 보이는 선행연구(H. J. Lim, 2014)와 유아의 기질을 프로파일 분석한 연구(Choi \& Yeon, 2014; J. H. Kim, 2015)에서 활동성 과 사회성이 높은 기질 집단이 확인된 바와 일치한다. 이에 어 머니가 유아의 발달을 효과적으로 돕기 위해서는 친사회성과 활발성을 특징으로 하는 기질적 특성을 고려하여 개별적인 양 육을 제공할 필요가 있다. 즉, 민주적 양육과 더불어 다양한 환 경탐색을 할 수 있는 환경을 마련함으로써, 유아가 자신의 사 교성 기질을 긍정적으로 발휘하여 놀이를 주도하고 타인을 이 끌 수 있는 능력을 향상시킬 수 있도록 도모할 필요가 있다.

그 다음 높은 비율로 속해 있는 부정적 정서성 유아 + 비일 관적 양육 프로파일은 유아의 부정적 정서성 기질 그리고 어 머니의 과보호·허용, 거부·방임 양육행동이 높게 나타났다. 까다로운 기질의 핵심 요소이기도 한 부정적 정서성(Thomas \& Chess, 1977)은 4개월에서 12개월까지 선형적으로 증가하 다가(Bridgett et al., 2009), 유아기에 정점을 이루고 그 이후 점 점 감소한다(Chang, 2015). 즉, 유아기는 자율성이 발달함에 따라 독립적으로 행동하려는 의지가 강해지게 되어 자신의 의 사를 고집하며 떼를 쓰게 된다. 하지만 언어로 자신의 감정이 나 행동을 표현, 통제하는 능력이 발달되지 않아, 짜증, 화, 울 음 등과 같은 부정적인 정서를 자주 표출하게 된다. 반면, 이 시기의 부모는 자녀가 말을 알아듣고 지시에 따르기를 기대하 지만(Shaw, Bell, \& Gilliom, 2000), 부정적인 정서를 자주 표출 하고 잘 달래지지 않는 자녀에 대해 스트레스를 받게 되고, 다 루기 힘들어짐에 따라 온정적인 양육보다는 통제적이고 강압 적인 양육을 택하게 된다(E. J. Kim, Park, \& Lim, 2009). 한편 저출산으로 인해 부모들이 한 명의 자녀를 위해 아낌없이 지 원하는 경향이 뚜렷해지면서 유아의 욕구를 무조건적으로 충 족시켜 주는 것이 올바른 양육방식이라는 왜곡된 양육 신념을 가지게 되었다(K.-M. Kim, Park, \& Kim, 2005). 이는 어머니로 하여금 부정적 정서성을 표현하는 자녀에게 허용적이고 과보 호적인 양육태도를 취하도록 했을 가능성도 있다. 이러한 결 과는 훈육 상황에서 부모가 자녀에게 굴복하면서 규칙을 부여
하지 않는 과하게 허용적인 모습과 체벌이나 꾸중으로 강하게 반응하는 강압적인 모습이 공존하는 양육방식이 나타난 선행 연구(Koo \& Park, 2018)에서도 확인 가능하다. 이처럼 어머니 의 비일관적인 양육을 경험한 유아는 혼란을 느끼게 되고, 심 리적인 어려움을 가질 가능성이 높아진다. 실제로 비일관적인 양육은 아동의 우울에 부정적인 영향을 미치는 것으로 나타났 다(S. Lee, 2017). 따라서 어머니가 유아의 부정적 정서성에 민 감하게 반응해주고 정해진 규준에 따라 훈육하는 일관된 양육 이 요구되며, 어머니가 바람직한 양육을 보일 수 있도록 부모 교육과 상담을 제공할 필요가 있다.

마지막으로 수줍음 유아 + 민주적 양육 프로파일은 유아 의 활동성과 사회성 기질이 낮으며, 어머니의 온정·격려, 한 계설정 양육행동이 높게 나타났다. 수줍음은 낮선 사람과 함 께 있는 상황에서 어려움을 보이고, 사회적 상호작용에 대한 회피적인 성향을 뜻한다. 유아의 수줍음 기질은 위축과 부적 응과 같은 내면화 문제행동에 영향을 주는 기질적 요인으로 (Jo \& Shin, 2017; Yang \& Bang, 2014), 어머니의 낮은 수준의 온정·격려 및 한계설정, 높은 수준의 과보호·허용 및 거부·방 임과 관련 있는 것으로 보고되고 있다(P.-Y. Kim, 2010). 하지만 본 연구의 수줍음 기질 유아 + 민주적 양육 집단의 어머니는 높은 수준의 온정·격려, 한계설정, 낮은 수준의 과보호·허용 및 거부·방임적 양육을 보이는 것으로 나타났다. 이는 새로운 상황에 회피적이고 조심스러워하는 유아에게 어머니가 오히 려 더 민주적인 양육을 보임으로써, 자녀와의 상호작용에 적 극적으로 참여하는 것으로 해석할 수 있다.

또 다른 해석으로는 겸손함과 상호의존성이 강조되는 아시 아 문화적 특성으로 설명할 수 있다. 주로 수줍음은 억제되고 내성적인 특성을 보이는 불안한 수줍음(anxious shyness)에 초 점이 맞춰져 연구가 이루어져왔다. 하지만 문화비교연구자들 이 한국의 초등학생에게서 겸손한 태도로 특징지어지는 조절 된 수줍음(regulated shyness)을 발견하였으며, 조절된 수줍음은 또래와 교사에 의해 받아들여질 가능성이 높음을 설명하였다 (Xu, Farver, \& Shin, 2014). 이에 따라 수줍음 유아 + 민주적 양 육 집단을 설명해보자면, 적극적으로 나서지 않는 겸손한 특 징을 보이는 유아에게 어머니가 온정적인 태도로 자녀를 수용 하고 격려하는 민주적인 양육을 보이는 집단으로 해석할 수 있다. 하지만 이 집단에 대한 연구가 부족한 실정이므로, 이 집 단에 대한 후속 연구가 이루어질 필요가 있다.

본 연구는 잠재프로파일 분석을 적용함으로써 유아 기질, 어머니 양육행동을 동시에 고려하여 질적으로 구분되는 기 질-양육 상호작용 양상을 확인하고자 하였다. 그 결과, 기존의 
변수중심접근에서 확인할 수 없었던 몇 가지 특징을 확인할 수 있었다.

첫째, $\mathrm{EAS}$ 척도의 기질(활동성, 정서성, 사회성)을 잠재프 로파일 분석한 결과, 적극적으로 환경을 탐색함으로써 다른 사람과 어울리는 것을 선호하는 사교성 기질 특성을 보이는 집단을 확인한 점이다. 이는 J. H. Kim (2015)과 Choi와 Yeon (2014)의 연구에서 활동성과 사회성이 동시에 높은 기질 집단 이 확인된 바와 일치하는 결과이며, 유아가 2개 이상의 기질 특성을 동시에 지닐 수 있기 있기 때문에 종합적인 관점에서 유아 기질을 살펴봐야함을 설명한 선행연구(J.-S. Lee \& Mun, 2011)를 지지하는 결과이다.

둘째, 부정적 정서성 유아 + 비일관적 양육 집단의 어머니 양육은 과보호·허용적 양육과 거부·방임적 양육이 동시에 높 게 나타났다. 기존 변수중심의 양육행동 선행연구에서는 온 정·격려, 한계설정, 과보호·허용, 거부·방임의 각각의 개별 특 성에 초점을 두어 연구가 이루어졌다. 하지만 현대사회의 변 화로 인해 어머니 양육특성 또한 다양해짐에 따라, 어머니 양 육행동을 복합적인 관점에서 살펴볼 필요성이 제기되어 왔다 (Koo \& Park, 2018). 따라서 현 시대에 맞는 새로운 접근에서 유 아기 자녀를 둔 어머니 양육행동의 다양성을 확인하고, 이에 부합하는 부모교육프로그램을 마련할 필요가 있을 것이다.

종합하면 유아의 기질과 어머니 양육행동의 프로파일을 확 인한 결과, 유아의 기질과 어머니의 양육행동 프로파일이 다 양하게 나타났다. 이는 가정환경에서 유아의 기질과 어머니 양육행동 상호작용 양상이 다양하게 나타날 수 있음을 확인했 다는 점에서 중요하다.

연구문제 2 와 관련하여, 유아의 기질과 어머니 양육행동 프 로파일에 따른 실행기능(억제, 전환, 작업기억)의 차이를 확인 한 결과, 프로파일 별로 실행기능 수준이 다른 것으로 나타났 다. 즉, 유아의 억제와 작업기억은 수줍음 유아 + 민주적 양육 집단과 사교성 유아 + 민주적 양육 집단이 부정적 정서성 유아 + 비일관적 양육 집단보다 높은 것으로 나타났다. 또한, 전환 은 사교성 유아 + 민주적 양육 집단이 부정적 정서성 유아 + 비 일관적 양육 집단과 수줍음 유아 + 민주적 양육 집단보다 높은 것으로 나타났다.

실행기능의 모든 하위 영역(억제, 전환, 작업기억)에서 사 교성 유아에게 어머니가 민주적 양육을 보일 때 가장 높은 실 행기능 수준을 보였다. 이는 새로운 자극에 쉽게 접근하고 적 응을 잘하는 유아와 애정적, 온정적인 양육을 보이는 어머 니의 실행기능 수준이 높은 것으로 나타난 선행연구(M. Cha \& Kim, 2018; Kong \& Lim, 2012; Lee et al., 2014; Yoo \& Kim,
2017)와 일치한다. 반면, 활동성과 실행기능 간 관계는 이전 연구와 불일치한 결과를 보인다. 선행연구에서는 유아의 높 은 활동성은 실행기능과 부적 관련성(Henning, Spinath, \& Aschersleben, 2011)을 보인 반면, 본 연구에서는 높은 활동성 과 사회성을 보이는 사교성 기질 집단이 제일 높은 실행기능 수준을 보이는 것으로 나타났다. 이러한 이유로는 본 연구에 서 측정한 EAS 기질 척도의 활동성 문항 내용에 기인한 것으 로 보인다. 문항을 살펴보면 "아침에 일어나자마자 나가서 논 다.", "항상 활동적이다.” 등의 5 가지 문항으로 이루어져 있다. 이는 어머니가 유아의 활동성을 평가하는 데에 있어 과한 신 체적 움직임과 산만한 특성보다는 활기 있는 건강한 기질 특 성으로 인식하여 평가했을 가능성이 있다. 즉, 본 연구에서 측 정된 활동성은 다양한 환경에 쉽게 접근하여 탐색함으로써, 유아가 인지적 정보를 처리하는 과정에서 오히려 적응적인 요 인으로 작용했을 가능성이 있다. 종합하면, 활발하며 사회적 인 상황에서 적극성을 가지고 다른 사람과 어울리는 성향을 가진 유아에게 어머니가 민주적인 양육을 보이는 집단의 실행 기능 수준이 제일 높은 것으로 나타났다.

한편 부정적 정서성 유아 + 비일관적 양육 집단이 제일 낮 은 실행기능 수준을 보였다. 이는 부정적 정서성 유아는 자신 의 인지를 통제.조절하는 데에 어려움을 보이는데, 이 때 어머 니의 비일관적인 양육을 경험하게 되면 더 큰 부정적인 영향 을 받게 되는 것으로 볼 수 있다. 이러한 결과는 까다로운 기질 의 유아가 부정적 양육을 경험하면 부적응적인 발달적 결과를 보일 수 있음을 설명하는 차별적 민감성 모델을 지지하는 결 과이다(Belsky \& Pluess, 2009). 반대로 차별적 민감성 모델은 까다로운 기질의 유아가 긍정적 양육을 경험하면 높은 발달 성취를 보일 수 있음을 설명한다. 관련하여 선행연구에서 유 아가 부정적 정서성을 보일지라도 어머니가 온정적이며 지지 적일 때, 유아의 실행기능 수준을 향상시킬 수 있음을 보고하 였다(Rochette \& Bernier, 2016). 따라서 부정적 정서성 유아 + 비일관적 양육 집단 유아의 실행기능을 향상시키기 위해서 어 머니가 온정·격려적이고 규준에 따라 자녀를 훈육하는 민주 적, 일관적인 양육을 보일 수 있도록 부모상담, 부모교육이 필 요함을 시사한다.

본 연구에서 실행기능 하위영역에 따라 몇 가지 특이점도 확인되었다. 억제와 작업기억 영역에서 수줍음 유아 + 민주 적 양육 집단과 사교성 유아 + 민주적 양육 집단 간 차이가 나 타나지 않은 점이다. 이는 수줍음 유아가 실행기능 능력에 어 려움을 보일지라도(Blankson, O'Brien, Leerkes, Marcovitch, \& Calkins, 2011), 어머니의 민주적인 양육을 경험하면 사교성 기 
질을 가진 유아만큼 억제, 작업기억 능력이 향상되는 것으로 볼 수 있다. 이러한 결과는 유아가 낯선 상황에서 긴장하는 성 향으로 인해 사회적 불안을 느끼게 되어 정보를 처리하는 과 정에서 어려움을 보일지라도 어머니의 온정적이고 수용적인 태도를 민감하게 받아들여 우세적인 반응을 의식적으로 억제 하고 정보를 기억할 수 있는 것으로 추측할 수 있다. 관련하여 선행연구에 의하면 유아의 수줍음으로 인한 위축 및 불안.우 울 문제가 어머니의 다양한 경험 제공과 유아의 감정 존중 태 도를 통해 완화되었다(Yang \& Bang, 2014). 따라서 수줍음 유 아의 억제, 작업기억 능력 발달을 돕기 위해서는 어머니의 민 주적 양육과 더불어 자녀가 새로운 환경에 적응할 수 있도록 도울 수 있는 다양한 환경을 제공할 필요가 있다.

반면, 전환능력에서는 수줍음 유아 + 민주적 양육 집단과 부정적 정서성 유아 + 비일관적 양육 집단 간 차이가 나타나지 않았다. 즉 어머니가 민주적인 양육을 보이더라도 유아가 수 줍음 기질을 지니면, 부정적 정서성 기질 + 비일관적 양육 집 단만큼 전환능력 발달이 저해됨을 의미한다. 이는 아마도 환 경적 변화에 민감하며 신중한 탐색 태도를 보이는 수줍음 성 향으로 인해 반응전환 혹은 과제전환과 같은 사고의 유연성을 특징으로 하는 전환능력에서 더 많은 어려움을 갖는 것으로 추측된다. 따라서 어머니는 자녀에게 민주적 양육과 더불어 전환능력을 향상시킬 수 있는 합리적 지도가 필요함을 알 수 있다. 즉, 환경적 변화에 민감하며 신중한 탐색 태도를 보이는 성향으로 인해 반응전환 혹은 과제전환과 같은 사고를 전환 하는 데에 어려움을 보이게 될 때, 어머니가 자녀의 흥미에 기 반을 둔 활동을 준비하거나, 다양한 친구 - 학습기회를 접할 수 있는 환경을 제공함으로써 자녀의 행동을 고려해야한다(Yang $\&$ Bang, 2014).

종합하면 유아의 적응적인 기질과 어머니의 긍정적 양육의 상호작용은 유아의 실행기능을 발달시키는 반면, 유아의 부적 응적인 기질과 어머니의 부정적 양육의 상호작용은 유아의 실 행기능을 저해하는 것으로 볼 수 있다. 이러한 결과는 유아의 기질에 맞는 어머니의 양육이 필요함을 시사한다. 즉 사교적 인 유아에게 어머니가 민주적인 양육을 보일 경우, 유아는 자 신의 사고와 행동에 대해 침착한 태도를 배우게 되어 자신의 인지를 억제하고 정보를 기억하며, 유연하게 조작과 마음상태 를 바꿀 수 있었다.

한편, 실행기능의 발달을 저해하는 부정적 정서성과 수줍 음은 어머니 양육행동에 따라 서로 다른 결과를 보였다. 부정 적 정서성 수준이 높은 유아에게 어머니가 비일관적 양육을 보이게 될 때, 유아의 실행기능 발달에 부정적인 영향을 미치
는 것으로 나타났다. 반면 유아가 수줍음 특성을 보이더라도 어머니가 민주적 양육을 보이는 경우, 유아의 실행기능 수준 은 비교적 높은 수준이었다. 따라서 유아의 실행기능 발달을 돕기 위해서는 양육자가 유아 개인의 기질적 특성을 이해하고 이에 적합한 양육행동을 습득할 필요가 있을 것이다.

본 연구의 결과를 토대로 다음과 같은 결론을 내릴 수 있다.

첫째, 유아의 기질과 어머니 양육행동의 프로파일을 확인 한 결과, 유아의 기질과 어머니의 양육행동 상호작용 양상이 다양하게 나타났다. 이는 가정환경에서 유아의 기질과 어머니 양육행동 상호작용 양상이 다양하게 나타날 수 있음을 확인했 다는 점에서 중요하다.

둘째, 유아의 기질과 어머니 양육행동 프로파일에 따라서 유아의 실행기능 하위영역 별 수준이 다르게 나타났다. 이는 유아의 억제, 작업기억, 전환능력을 향상시키기 위해서는 유 아의 기질과 어머니 양육행동이 최적의 조화를 이루어야 함을 의미한다. 또한, 부적응적인 기질에 대해 어머니가 유아의 기 질적 특성을 이해하고 인지하여 긍정적인 양육을 보일 수 있 어야 한다.

본 연구의 의의는 잠재프로파일 분석을 통해 유아의 기질 적 특성과 어머니 양육행동을 동시에 고려함으로써, 이질적 잠 재집단유형을 확인하였다는데 있다. 또한 유아의 실행기능 발 달에 있어 유아의 기질과 어머니 양육행동이 각기 영향을 미치 는 것이 아니라 상호작용하여 영향을 미친다는 것을 확인하였 으며, 유아의 다양한 기질적 특성을 고려한 어머니 양육행동이 요구됨을 경험적으로 확인하였다는 점에서 의의가 있다.

마지막으로 본 연구의 제한점은 다음과 같다.

첫째, 실행기능의 평균점수가 억제 3.62, 전환 3.62, 작업기 억 3.61로 높게 나타났다. 이는 어머니가 유아의 실행기능을 평가할 때, 주관적 판단으로 인해 유아의 실제 능력보다 더 높 게 평가했기 때문으로 보인다. 따라서 후속연구에서 실행기능 과제수행 평가와 질문지를 함께 고려할 필요가 있다.

둘째, 유아의 기질과 어머니의 양육행동 잠재프로파일 유형 에 관한 경험적 연구의 제한으로 인해, 본 연구결과의 일반화 가능성에 대해서는 추후 연구들을 통해 확인할 필요가 있다.

셋째, 실행기능은 만 3-5세에 급격하게 발달하기 때문에 연 령에 따른 차이가 있는 것으로 보고되고 있다. 하지만 본 연구 는 연령효과를 고려하지 않았다. 이에 후속연구에서 연령을 고려하여 세부적인 발달차를 연구할 필요가 있다. 


\section{Notes}

This article is a part of the first author's master's thesis submitted in 2020, and was presented as a poster at the 2019 Annual Fall Conference of the Korean Association of Child Studies.

\section{Conflict of Interest}

No potential conflict of interest relevant to this article was reported.

\section{References}

\section{In English}

Belsky, J., \& Pluess, M. (2009). Beyond diathesis stress: Differential susceptibility to environmental influences. Psychological Bulletin, 135(6), 885-908. doi:10.1037/a0017376

Blankson, A. N., O’Brien, M., Leerkes, E. M., Marcovitch, S., \& Calkins, S. D. (2011). Shyness and vocabulary: The roles of executive functioning and home environmental stimulation. Merrill-Palmer Quarterly, 57(2), 105-128. doi:10.1353/mpq.2011.0007

Bridgett, D. J., Gartstein, M. A., Putnam, S. P., McKay, T., Iddins, E., Robertson, C.,... Rittmueller, A. (2009). Maternal and contextual influences and the effect of temperament development during infancy and parenting in toddlerhood. Infant Behavior and Development, 32(1), 103-116. doi:10. 1016/j.infbeh.2008.10.007

Buss, A. H., \& Plomin, R. (2014). Temperament: Early developing personality traits. New York: Psychology Press.

Carlson, S. M. (2005). Developmentally sensitive measures of executive function in preschool children. Developmental Neuropsychology, 28(2), 595-616. doi:10.1207/s15326942dn2802_3

Caron, J., \& Miller, P. (1981). Effects of infant characteristics on caregiver responsiveness among the Gusii. Paper presented at the meeting of the Society for Research in Child Development, Boston, MA.

Dalimonte-Merckling, D. M., \& Brophy-Herb, H. E. (2019). A person-centered approach to child temperament and parenting. Child Development, 90(5), 1702-1717. doi:10.1111/ cdev. 13046

Garon, N., Bryson, S. E., \& Smith, I. M. (2008). Executive function in preschoolers: A review using an integrative framework. Psychological Bulletin, 134(1), 31-60. doi:10.1037/00332909.134.1.31
Giancola, P. R. (1995). Evidence for dorsolateral and orbital prefrontal cortical involvement in the expression of aggressive behavior. Aggressive behavior, 21(6), 431-450. doi:10.1002/10982337(1995)21:6<431::AID-AB2480210604>3.0.CO;2-Q

Gioia, G. A., Isquith, P. K., Guy, S. C., \& Kenworthy, L. (2000). Test review behavior rating inventory of executive function. Child Neuropsychology, 6(3), 235-238. doi:10.1076/chin. 6.3.235.3152

Henning, A., Spinath, F. M., \& Aschersleben, G. (2011). The link between preschoolers' executive function and theory of mind and the role of epistemic states. Journal of Experimental Child Psychology, 108(3), 513-531. doi:10.1016/j.jecp.2010.10.006

Laursen, B. P., \& Hoff, E. (2006). Person-centered and variablecentered approaches to longitudinal data. Mer-rill-Palmer Quarterly, 52(3), 377-389. doi:10.1353/mpq.2006.0029

Maccoby, E. E., \& Martin, J. A. (1983). Socialization in the context of the family: Parent-child interaction. In P. H. Mussen \& E. M. Hetherington (Eds.), Handbook of child psychology: Vol. 4. Socialization, Personality, and Social Development (pp. 1-101). New York: Wiley.

McManis, M. H., Kagan, J., Snidman, N. C., \& Woodward, S. A. (2002). EEG asymmetry, power, and temperament in children. Developmental psychobiology, 41(2), 169-177. doi:10.1002/dev.10053

Miyake, A., Friedman, N. P., Emerson, M. J., Witzki, A. H., Howerter, A., \& Wager, T. D. (2000). The unity and diversity of executive functions and their contributions to complex "frontal lobe" tasks: A latent variable analysis. Cognitive Psychology, 41(1), 49-100. doi:10.1006/cogp.1999.0734

Mplus (Version 8.1). [Computer software]. Los Angeles, CA: Muthén \& Muthén.

Nelson, C. A., \& Bloom, F. E. (1997). Child development and neuroscience. Child Development, 68(5), 970-987. doi:10. 2307/1132045

Rochette, É., \& Bernier, A. (2016). Parenting and preschoolers' executive functioning: A case of differential susceptibility? International Journal of Behavioral Development, 40(2), 151161. doi: $10.1177 / 0165025414557370$

Shaw, D. S., Bell, R. Q., \& Gilliom, M. (2000). A truly early starter model of antisocial behavior revisited. Clinical Child and Family Psychology Review, 3, 155-172. doi:10.1023/ A: 1009599208790

Suor, J. H., Sturge-Apple, M. L., Davies, P. T., \& Jones-Gordils, H. R. (2019). The interplay between parenting and temperament in associations with children's executive function. Journal of Family Psychology, 33(7). 841-850. doi:10.1037/fam0000558

Thomas, A., \& Chess, S. (1977). Temperament and development. New York: Brunner/Marzel.

Welsh, M. C., Pennington, B. F., \& Groisser, D. B. (1991). A normativedevelopmental study of executive function: A window on 
prefrontal function in children. Developmental Neuropsychology, 7(2), 131-149. doi:10.1080/87565649109540483

Xu, Y., Farver, J. A. M., \& Shin, Y. (2014). Shyness and psychosocial functioning in South Korean children. European Journal of Personality, 28(2), 147-155. doi:10.1002/per.1938

Zhou, Q., Chen, S. H., \& Main, A. (2012). Commonalities and differences in the research on children's effortful control and executive function: A call for an integrated model of self-regulation. Child Development Perspectives, 6(2), 112121. doi:10.1111/j.1750-8606.2011.00176.x

\section{In Korean}

Cha, K. (2015). Maternal interaction behaviors and the development of executive functions among Korean preschoolers. Korean Journal of Early Childhood Education, 35(2), 117-141. doi:10.18023/kjece.2015.35.2.006

Cha, M. (2018). Relationships among preschoolers' executive function, preschool adjustment, school readiness, temperament, and maternal parenting (Master's thesis). Retrieved from http:// www.riss.kr/link?id=T14712237

Cha, M., \& Kim, K. (2018). The effects of temperament and maternal parenting on preschoolers' executive function. Journal of Parent Education, 10(1), 115-137

Chang, H. (2015). Reciprocal relations between child negative emotionality and maternal depression: A transactional model. The Korean Journal of Developmental Psychology, 28(2), 19-39.

Cheon, S. Y. (2002). The differential developmental pattern by child temperamental types and parental styles: A study on 'goodness of fit' in a developmental context (Master's thesis). Retrieved from http://www.riss.kr/link?id=T8370880

Choi, H., \& Yeon, E. M. (2014). Effects of child temperament on fathers' parenting behaviors and married life. Korean Joural of Children's Media, 13(3). 125-148.

Hong, S. (2019). Program 3: Jamjaegyecheung, jamjaejeoni, seongjanghonhammohyeong [Program 3: 잠재계층, 잠재전 이, 성장혼합모형]. Seoul: Bagyeongsa.

Jo, W. R., \& Shin, N. (2017). Effects of young children's shyness on social withdrawal of young children: Focusing on moderating effects of teacher-child relationships. Family and Environment Research, 55(4), 419-431. doi:10.6115/ fer.2017.030

Kim, B. Y. (2016). The effect of children's executive function, selfesteem and emotional intelligence on peer competence. Early Childhood Education and Care, 11(3), 29-51. doi:10. 16978/ecec.2016.11.3.002

Kim, E. J., Park, S. Y., \& Lim, H. S. (2009). The effects of child gender and temperament, husbands' support, and mothers' psychological well-being on maternal parenting behaviors toward toddlers. Journal of the Korean Home Economics Association, 47(9), 71-82.

Kim, H. J., \& Hong, S. O. (2011). A comparison of executive function between gifted and non-gifted young children. The Korea Open Association for Early Childhood Education 16(3), 259-280.

Kim, J. H. (2015). Differences in mothers' psychological characteristic, parenting stress by childs' temperament profiles. Korean Journal of Early Childhood Education, 35(1), 135-152. doi:10.18023/kjece.2015.35.1.006

Kim, K.-M., Park, B.-K., \& Kim, Y.-H. (2005). A study of intergenerational transmission of childhood maltreatment: A comparison of mothers of children with emotional disorder and mothers of normal children. The Journal of Play Therapy, 9(1), 23-37.

Kim, M.-H. (2014). Mother's verbal control modes and children's executive function (Master's thesis). Retrieved from http:// www.riss.kr/link?id=T13481889.

Kim, M. J., \& Lee, K. N. (2011). Effects of infants' and toddlers' temperament and mothers' parenting self-efficacy on parenting behavior. Korean Association Child Care and Education, 7(4), 253-271.

Kim, P.-Y. (2010). The relationship between a child's shyness and a mother's nurturing attitude (Master's thesis). Retrieved from http://www.riss.kr/link?id=T12159569

Kim, S. L. (2016). The moderating effects of mothers' parenting styles on the relationship between preschoolers' temperament and their behavior problems. Journal of Life-span Studies, 6(1), 1-20.

Kim, Y.-M. (2018). The development of children's hot and cool executive function and relationship between language ability. Journal of Future Early Childhood Education, 25(3), 131-157. doi:10.22155/JFECE.25.3.131.157

Kong, Y.-S., \& Lim J.-Y. (2012). The effect of preschooler's temperament and maternal parenting attitude on preschooler's problem and prosocial behaviors-Focusing on the mediating effect of cool executive function-. Journal of Early Childhood Education, 32(2), 351-375. doi:10.18023/kjece.2012.32.2.016

Koo, J. Y., \& Park, K. J. (2018). Parenting profiles and children's social skills: The mediating role of effortful control. Korean Journal of Child Studies, 39(1), 89-101. doi:10.5723/kjcs.2018.39.1.89

Lee, E. Y. (2009). The effects of children's temperament and maternal child-rearing attitude on their children's social development (Master's thesis). Retrieved from http://www.riss.kr/link?id= T11732241

Lee, J.-S., \& Mun, B. (2011). The effects of preschooler's temperament, mother's parenting stress and emotion regulation strategies on behavior problems in preschoolers-Focusing on the clusters by temperamental factors-. Korean Journal of Child Psychotherapy, 6(1), 81-97. 
Lee, J.-Y., \& Yu, J.-I. (2019). The effects of maternal overprotection on young children's executive function: The moderating effects of grit. Journal of Future Early Childhood Education, 26(3), 23-42. doi:10.22155/JFECE.26.3.23.42

Lee, M.-J., \& Hong, C.-H. (2006). Dimensions and development of executive function. The Korean Journal of Clinical Psychology, 25(2), 587-602.

Lee, S. (2017). The effects of inconsistent parenting on children for somatic symptoms and school adjustment. Global Social Welfare Review, 7(2), 63-77.

Lee, Y.-J., Kong, Y.-S., \& Lim, J.-Y. (2014). The effects of parenting behaviors on preschoolers executive function. Journal of Korean Home Management Association, 32(1), 1326. doi:10.7466/JKHMA.2014.32.1.13

Lim, H. J. (2014). A study of the effects of a mother's parenting style, her child's gender and temperament on the child's peer interactions. Journal of Early Childhood Education, 34(6), 5-27. doi:10.18023/kjece.2014.34.6.001

Maeng, S. H., Jeong, Y., \& Kwon, M.-K. (2014). Development of executive function and its relation to mathematical ability: Scale and graph understanding. The Korean Journal of Developmental Psychology, 27(1), 95-115.

Park, B.-K. (2013). Relations among toddlers' temperament, maternal parenting, and social withdrawal and aggression. Journal of Korean Home Management Association, 31(6), 6781. doi:10.7466/JKHMA.2013.31.6.67

Park, J. (2001). Children's peer competence in relation to maternal parenting goals, parenting behaviors, and management strategies of peer relations (Master's thesis). Retrieved from http://www.riss.kr/link?id=T7912822

Seo, J., \& Park, H. (2011). The effects of emotional intelligence on executive function: A comparison between normal children and attention deficit children. Journal of Cognitive Enhancement and Intervention, 2(1), 99-127.

Yang, M. J., \& Bang, H. J. (2014). The relation among shyness, cognitive ability, maternal parenting behaviors, withdrawal and anxiety. depression: Moderation effect of maternal parenting behaviors. Journal of Emotional \& Behavioral Disorders, 30(4), 363-386.

Yoo, R. H., \& Kim, S. H. (2017). The relationship between mothers' affective parenting and preschoolers' peer competence: Mediating effects of preschoolers' executive function and emotion regulation. Korean Journal of Child Studies, 38(2), 67-79. doi:10.5723/kjcs.2017.38.2.67

\section{ORCID}

Hye Rin Lee http://orcid.org/0000-0002-5880-2001

Sunhee Kim http://orcid.org/0000-0002-0801-6918

Received October 31, 2019

Revision received December 20, 2019

Accepted March 13, 2020 